Brit. J. prev. soc. Med. (1968), 22, 81-85

\title{
SOME EPIDEMIOLOGICAL ASPECTS OF DOWN'S SYNDROME IN BRITISH COLUMBIA
}

\author{
BY \\ P. A. BAIRD, M.D., C.M. (McGill), Research Fellow, \\ AND \\ J. R. Miller, M.A. (Toronto), Ph.D. (McGill), Associate Professor \\ From the Division of Medical Genetics, Department of Paediatrics, \\ University of British Columbia, \\ and the Registry for Handicapped Children and Adults. \\ Department of Health and Hospital Insurance, British Columbia, Canada
}

If an infectious illness causes congenital malformations then those malformations would be expected to occur in clusters as does the infection itself. There is some evidence that chromosomal abnormalities may be non-randon-that is, that cases occur in clusters (Robinson and Puck, 1965; Hecht, Bryant, Gruber, and Townes, 1964; Day, 1966). Many workers have speculated on the cause of this "nonrandomness", with virus infections being strongly considered, as viruses are well known to affect chromosomes, e.g. by causing breakages (Nichols, 1966).

Pleydell (1957) reported that many of the births with Down's syndrome (mongolism) in Northamptonshire seemed to be aggregated in a way that suggested an infectious aetiological agent. Further evidence occurred in 1963 with a brief report of three clusters of such births occurring in South Dakota (Heinrichs, Allen, and Nelson). Since 1962 several reports have been made by Collmann and Stoller from the state of Victoria, Australia, where they have found a 5-year peak cycle of incidence of Down's syndrome births with rural peaks lagging behind urban by a year. They found that this pattern of occurrence corresponds closely to that of infectious hepatitis 9 months previously, and that many of their cases occurred in clusters (Collmann and Stoller, 1962a, b; Stoller and Collmann, 1965). Stark and Fraumeni (1962) and Ceccarelli and Torbidoni (1967), testing this hypothesis, compared the incidence of viral hepatitis with that of Down's syndrome among children born 9 months later and found no evidence for a correlation. None of these studies made use of a statistical technique for detecting space-time clustering.
Leck (1966) reported a study of the epidemicity of Down's syndrome from Birmingham using Knox's method (1963) for detecting clustering. He concluded that the incidence may be affected by an epidemic agent, but that this is of less aetiological importance than has sometimes been suggested.

The purpose of this study was to examine data on births with Down's syndrome in British Columbia for periodicity in incidence, and for any correlation with the incidence of infectious hepatitis. A statistical technique for detection of space-time clustering in such births was employed.

\section{MeTHODS}

The source of the cases was the Registry for Handicapped Children and Adults in British Columbia (Miller, 1964; Mott, 1963). Cases in the Registry with Down's syndrome born between 1952 and 1960 were studied. Active registration began in 1952, and 1960 was taken as the last year of the study to allow time for registration of the small proportion of cases who are not registered until they reach kindergarten age (Renwick, 1966). Yearly and quarterly incidence rates of births with the syndrome were obtained and examined with regard to periodicity and for any relation to infectious hepatitis and several other notifiable infectious diseases 9 months previously.

The method of Ederer, Myers, and Mantel (1964) was used to detect space-time clustering in occurrence of cases. This method was chosen as it has been shown that, using a calendar year as a unit of time and a Connecticut town as a unit of space, it readily detects hepatitis clustering (Ederer, Myers, Eisenberg, and Campbell, 1965). For this, the place of residence 
at the time of birth was used. The 5-year period 1954-58 was chosen to examine for clusters because during this length of time the population can be taken to be stable which is necessary using Ederer's formula.

The data were analysed in two ways for clustering:

(1) The unit of space was a town of a size such that between 150 and 350 births per year by residence occurred. This size was chosen to be comparable to the unit used by Ederer-Myers-Martel. Every town of this size in the Province was analysed. There was a total of 31 such towns.

(2) A group of geographically adjacent census subdivisions with approximately 2,000 births per year was used as the unit of place. Victoria, Vancouver, and the adjacent areas (Fig. 1) were excluded from this analysis as the demographic data available for these regions could not be broken down into comparable place units. These areas account for approximately 60 per cent. of the population of British Columbia which was about $1 \frac{1}{2}$ million during this time.

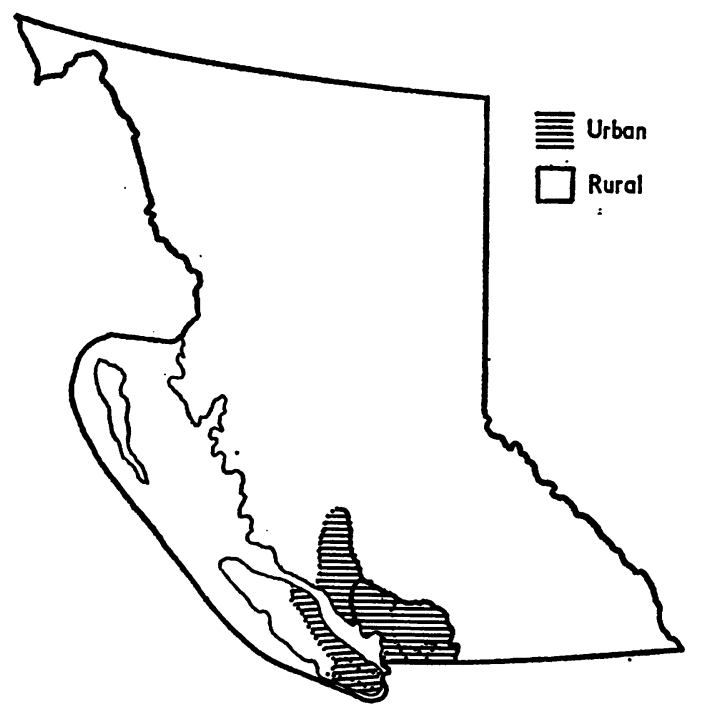

FIG. 1.-Rural and urban areas of British Columbia as used for analysis of data.

The figures for population and birth statistics were obtained from the Vital Statistics Branch of the British Columbia Department of Health Services and Hospital Insurance and the infectious disease data from the Health Branch of the Department.

\section{INCIDENCE}

\section{RESULTS}

As is seen in Table I, 411 cases of Down's syndrome were registered during the period 1952-60.
TABLE I

ANNUAL INCIDENCE OF DOWN'S SYNDROME AMONG LIVE BIRTHS IN BRITISH COLUMBIA

\begin{tabular}{c|c|c|c}
\hline Year of Birth & $\begin{array}{c}\text { Number } \\
\text { Affected }\end{array}$ & $\begin{array}{c}\text { All Live } \\
\text { Births }\end{array}$ & $\begin{array}{c}\text { Incidence per } \\
\text { 1,000 Live Births }\end{array}$ \\
\hline 1952 & 38 & 29,827 & $1 \cdot 27$ \\
1953 & 46 & 31,746 & $1 \cdot 45$ \\
1954 & 42 & 32,946 & $1 \cdot 27$ \\
1955 & 50 & 34,138 & $1 \cdot 46$ \\
1956 & 37 & 36,241 & $1 \cdot 02$ \\
1957 & 44 & 38,744 & $1 \cdot 14$ \\
1958 & 47 & 39,577 & $1 \cdot 19$ \\
1959 & 52 & 39,971 & $1 \cdot 30$ \\
1960 & 55 & 40,116 & $1 \cdot 37$ \\
\hline Total & 411 & 323,306 & $1 \cdot 27$ \\
\hline
\end{tabular}

No significant deviation from mean for year. $x^{2}=4 \cdot 70 ; 8$ d.f.; $0.8>P>0.7$.

During this period there were 326,306 live births in the Province, giving an incidence rate of $1 \cdot 27$ per 1,000 live births. There was no significant deviation from the mean for the years, and no 5-year cycle was detected. The incidence of cases in each quarter was determined, and only one - the first quarter of 1955 - 은 deviated significantly from the mean $(0.05>-$ $P>0.02)$. The overall seasonal incidence showed no significant deviation (Table II).

TABLE II

QUARTERLY RATES OF DOWN'S SYNDROME, 1952-600

\begin{tabular}{|c|c|c|c|c|}
\hline Quarter & & $\begin{array}{c}\text { No. of } \\
\text { Cases of } \\
\text { Down's } \\
\text { Syndrome }\end{array}$ & $\begin{array}{l}\text { No. of } \\
\text { Live Births }\end{array}$ & $\begin{array}{l}\text { Incidence } \\
\text { per } 1,000 \\
\text { Live Births }\end{array}$ \\
\hline $\begin{array}{l}\text { January-March. . } \\
\text { April-June } \ldots \\
\text { July-September . } \\
\text { October-December }\end{array}$ & $\begin{array}{l}\cdots \\
\cdots \\
\cdots\end{array}$ & $\begin{array}{r}99 \\
110 \\
105 \\
97\end{array}$ & $\begin{array}{l}77,291 \\
82,876 \\
84,255 \\
78,884\end{array}$ & $\begin{array}{l}1 \cdot 29 \\
1.33 \\
1 \cdot 25 \\
1 \cdot 23\end{array}$ \\
\hline Total .. & $\ldots$ & 411 & 323,306 & $1 \cdot 27$ \\
\hline
\end{tabular}

The incidence of infectious hepatitis in each year was compared with the incidence of cases in the year beginning in October of the same year and ending in September of the next (Table III), but no definite correlations were observed (Fig. 2). In particular, if broken down into quarters, marked peaks of infectious hepatitis in the first quarters of 1954, 1955, 1959, and 1960 were not followed by a rise in incidence of births with the syndrome 9 months later.

\section{INFECTIONS}

No correlation was found between the yearly incidence of Down's syndrome and that of several notifiable diseases (streptococcal infection, chicken pox, influenza, measles, mumps, poliomyelitis, and rubella). A severe influenza epidemic in 1957 was not followed by any increase in incidence of births with the syndrome 9 months later, nor were marked peaks in incidence of poliomyelitis in 1952 and 1963, and of rubella in 1956. Unfortunately, the last five 
TABLE III

INCIDENCE OF INFECTIOUS HEPATITIS COMPARED WITH THAT OF DOWN'S SYNDROME 9 MONTHS LATER

\begin{tabular}{|c|c|c|c|c|c|}
\hline \multicolumn{2}{|c|}{ Infectious Hepatitis } & \multicolumn{4}{|c|}{ Down's Syndrome } \\
\hline Year & $\begin{array}{l}\text { Number of Cases Reported } \\
\text { per } 100,000 \text { Population }\end{array}$ & $\begin{array}{l}\text { Year of Birth } \\
\text { (Oct.-Sept.) }\end{array}$ & $\begin{array}{l}\text { No. of } \\
\text { Cases }\end{array}$ & $\begin{array}{l}\text { No. of } \\
\text { Live Births }\end{array}$ & $\begin{array}{c}\text { Incidence per 1,000 } \\
\text { Live Births }\end{array}$ \\
\hline $\begin{array}{l}1952 \\
1953 \\
1954 \\
1955 \\
1956 \\
1957 \\
1958 \\
1959 \\
1960\end{array}$ & $\begin{array}{l}17 \cdot 7 \\
63 \cdot 2 \\
94 \cdot 2 \\
62 \cdot 6 \\
24 \cdot 5 \\
26 \cdot 4 \\
36 \cdot 3 \\
57 \cdot 9 \\
57 \cdot 7\end{array}$ & $\begin{array}{l}1952-53 \\
1953-54 \\
1954-55 \\
1955-56 \\
1956-57 \\
1957-58 \\
1958-59 \\
1959-60 \\
1960-61\end{array}$ & $\begin{array}{l}45 \\
42 \\
52 \\
32 \\
42 \\
54 \\
49 \\
53 \\
50\end{array}$ & $\begin{array}{l}31,107 \\
32,966 \\
33,655 \\
35,860 \\
37,901 \\
39,604 \\
39,811 \\
40,525 \\
38,542\end{array}$ & $\begin{array}{l}1.45 \\
1.27 \\
1.54 \\
0.89 \\
1.11 \\
1.36 \\
1.23 \\
1.31 \\
1.30\end{array}$ \\
\hline Total & & & 419 & 329,971 & $1 \cdot 27$ \\
\hline
\end{tabular}

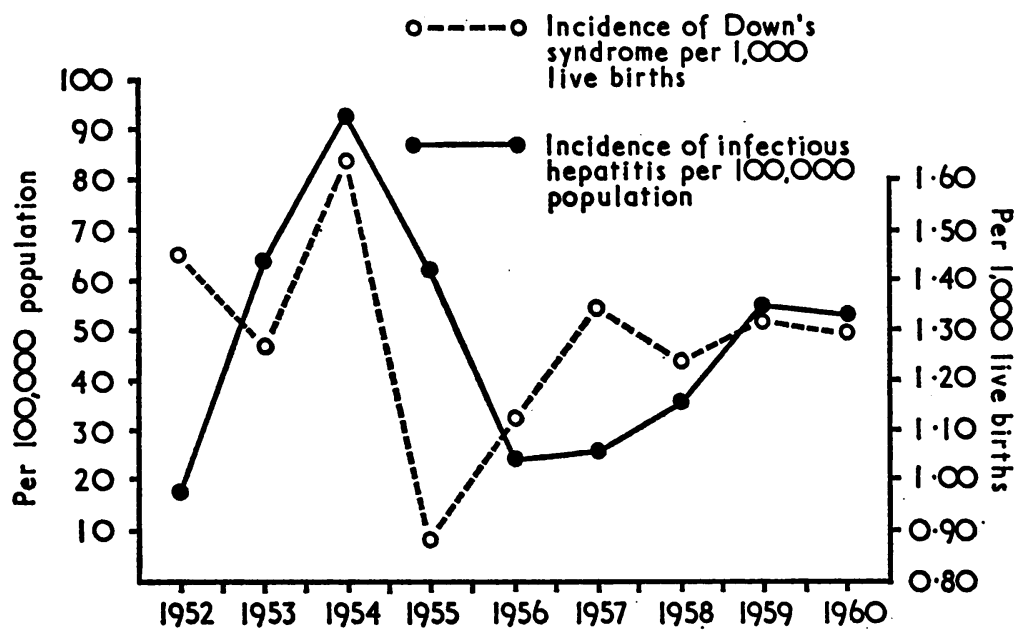

Fig. 2.-Number of cases of infectious hepatitis per 100,000 population of British Columbia compared with the incidence of Down's syndrome per 1,000 live births 9 months later.

diseases listed were not considered notifiable after 1957 and comparisons could therefore be made only to this time.

\section{URBAN AND RURAL}

The urban and rural rates of incidence of cases were compared. For this purpose Victoria, Vancouver, and their adjacent areas were considered urban, and the rest of the Province rural (Fig. 1). As contrasted with the results of Collmann and Stoller $(1962 a, b)$, there was no lag of one year in rural as compared to urban peaks, and no relation was found between changes in yearly incidence in urban and rural areas (Table IV). The difference between the overall incidence for urban and rural areas (1.35 and $1 \cdot 11$ per 1,000 live births) was large but was not statistically significant $(P \simeq 0.06)$. To ascertain if this greater incidence in urban areas was due to a maternal age effect, the ages of parturient mothers in urban as opposed to rural areas for 1955 were
TABLE IV

INCIDENCE OF DOWN'S SYNDROME PER 1,000 LIVE BIRTHS IN BRITISH COLUMBIA

\begin{tabular}{c|c|c|c}
\hline Year & Overall Incidence & Urban & Rural \\
\hline 1952 & 1.27 & 1.50 & 0.82 \\
1953 & 1.45 & 1.47 & 1.42 \\
1954 & 1.27 & 1.45 & 0.92 \\
1955 & 1.46 & 1.67 & 1.05 \\
1956 & 1.02 & 0.99 & 1.08 \\
1957 & 1.14 & 1.28 & 0.77 \\
1958 & 1.19 & 1.21 & 1.14 \\
1959 & 1.30 & 1.35 & 1.21 \\
1960 & 1.37 & 1.31 & 1.50 \\
\hline Total & 1.27 & 1.35 & 1.11 \\
\hline
\end{tabular}

examined; $13 \cdot 3$ per cent. of rural mothers and $13 \cdot 9$ per cent. of urban mothers were aged 35 years or older. This difference is not statistically significant ( $P$ was between $0 \cdot 1$ and $0 \cdot 2$ ).

\section{Clusters}

No more time-space clustering of births with Down's syndrome was found than could be expected 
to occur by chance in the towns examined. $(0 \cdot 3>$ $\mathbf{P}>0.2$ for one-year clusters; $0.2>\mathbf{P}>\mathbf{0 . 1}$ for two-year clusters). The same method was used in looking for clustering of cases in census division areas. Here again no more clustering was found than that to be expected by chance $(0.5>P>0.3$ for one-year clusters; $0.7>\mathrm{P}>0.5$ for two-year clusters). As this method had not been used with such large space units before, actual cases of hepatitis from similar space units were analysed for clustering, to make sure that the method was valid. Highly significant clustering was found. $(\mathrm{P}<0.001$ for one-year and two-year clusters).

\section{Discussion}

As the registration of Down's syndrome in British Columbia is not compulsory, the incidence would be expected to be less than that of Penrose (1954) or Leck (1966), whose ascertainment was more complete, and this was found to be the case. The main sources of registration are practising physicians, public health personnel, visiting clinics, schools, personnel of institutions admitting children for special care and education, and birth certificates. There is no reason to think that the proportion registered differs from year to year, and therefore the numbers should reflect changes in incidence when these occur.

The tendency towards a significantly smaller number of births with the syndrome in rural areas may not be a reflection of an actual difference, but may possibly be due to better case-finding in urban areas. A rural-urban difference in case-finding would not invalidate the comparisons of the data which have been made, as these are between similar areas or between different times in the same area.

Stoller and Collman (1966) have pointed out that the age structures of mothers in the populations described by Leck (1966) and Stark and Fraumeni (1966) were not known, and that if the proportion of mothers aged 35 years and over in these studies was smaller than in the population studied by Stoller and Collmann this could be one reason for the different results. The percentage of mothers aged 35 and over in the report of Collmann and Stoller (1962a) fell from $15 \cdot 2$ per cent. in 1942 to $12 \cdot 9$ per cent. in 1957. The percentage of mothers aged 35 years and over in British Columbia for the years of the study was very similar-remaining just above 13 per cent. with no downward trend.

The apparent absence of periodicity of infectious hepatitis in Birmingham is felt by Collmann and Stoller to be related to the fact that the disease is not notifiable. It is notifiable in British Columbia and two peaks in the incidence of this disease 5 years apart were seen.

\section{SUMMARY}

Data on births with Down's syndrome in British Columbia were examined for periodicity in incidence and for any relation to infectious hepatitis.

No significant variation in yearly or seasonal incidence of births with the syndrome was found.

The incidence of such births could not be correlated with the incidence of infectious hepatitis 9 months previously. This lack of correlation applied also to the yearly incidence of seven other infectious diseases, although the period examined in the latter group was shorter.

There was a tendency to a higher incidence of births with the syndrome in urban as opposed to rural areas.

Using the method of Ederer, Myers, and Mantel (1964), no clustering of cases of Down's syndrome was found, although a highly significant clustering of hepatitis was detected.

It is concluded that if infectious hepatitis has any effect on the incidence of Down's syndrome it does not appear to be marked in the Province of Britisi Columbia.

Miss A. E. Scott and the staff of the Registry (which is supported by a National Health Grant), Mr Guy Renwick, and other members of the staff of the Division of Vital Statistics, Health Branch, Department of Health and Hospital Insurance, supplied all the data and much cheerful help.

\section{REFERENCES}

Ceccarelli, G., and Torbidoni, L. (1967). Lancet, 1, 438 (Letter to the Editor, Viral hepatitis and Down's syndrome).

Collmann, R. D., and Stoller, A. (1962a). "Proceedings of the London Conference on the Scientific Study of Mental Deficiency, 1960", ed. B. W. Richards, vol. 2, p. 517. May and Baker, Dagenham. (Notes on the epidemiology of mongolism in Victoria, Australia, from 1942 to 1957 .)

- (1962b). Amer. J. Publ. Hlth, 52, 813 (A $\frac{D}{O}$ survey of mongoloid births in Victoria, Australia, 1942-1957).

Day, R. W. (1966). Amer. J. hum. Genet., 18, 70 (The

Ederer, F., Myers, M. H., Eisenberg, H., and Campbell, P. C. (1965). J. Nat. Cancer Inst., 35, 625, (Temporalspatial distribution of leukemia and lymphoma in Connecticut).

(A. - and Mantel, N. (1964). Biometrics, 20, 626 (A statistical problem in space and time: do leukemia cases come in clusters?).

Hecht, F., Bryant, J. S., Gruber, D., and Townes, P. L. (1964). N. Engl.J. Med., 271, 1081 (The nonrandomness of chromosomal abnormalities). 
Heinrichs, E. H., Allen, S. W., and Nelson, P. S. (1963). Lancet, 2, 468 (Letter to the Editor, Simultaneous 18trisomy and 21-trisomy cluster).

Knox, G. (1963). Brit. J. prev. soc. Med., 17, 121 (Detection of low intensity epidemicity).

Leck, I. (1966). Lancet, 2, 457 (Incidence and epidemicity of Down's syndrome).

Miller, J. R. (1964). "II International Conference on Congenital Malformations, New York City, 1963", papers and discussions, p. 334. (The use of registries and vital statistics in the study of congenital malformations.)

Mott, G. A. (1963). Canad. J. Publ. Hlth, 54, 239 (The Registry of handicapped children and adults in British Columbia).

Nichols, W. W. (1966). Amer. J. hum. Genet., 18, 81 (The role of viruses in the etiology of chromosomal abnormalities).
Penrose, L. S. (1954). Ann. N.Y. Acad. Sci., 57, 494 (Mongolian idiocy (mongolism) and maternal age).

Pleydell, M. J. (1957). Lancet, 1, 1314 (Mongolism and other congenital abnormalities. An epidemiological study in Northamptonshire).

Renwick, D. H. G. (1966). Vital Statistics Branch, unpublished data.

Robinson, A., and Puck, T. T. (1965). Science, 148, 83 (Sex chromatin in newborns: presumptive evidence for external factors in human nondisjunction).

Stark, C. R., and Fraumeni, J. F. (1966). Lancet, 1, 1036 (Letter to the Editor, Viral hepatitis and Down's syndrome).

Stoller, A., and Collmann, R. D. (1965). Ibid., 2, 1221 (Incidence of infective hepatitis followed by Down's syndrome nine months later).

(1966). Ibid., 2, 859 (Letter to the Editor: Viral hepatitis and Down's syndrome). 